\title{
EFFECT OF FEEDING AFLATOXIN DIETS WITH AND WITHOUT HUMATE AND HYDRATED SODIUM CALCIUM ALUMINOSILICATE ON SOME REPRODUCTIVE AND BLOOD BIOCHEMICAL PARAMETERS OF LOCAL CHICKEN STRAIN
}

\author{
R.A. Hassan \\ Animal Production Research Institute, Agricultural Research Center, Ministry of \\ Agriculture, Dokki, Cairo, Egypt
}

\section{SUMMARY}

A total number of 180 hens plus 48 cocks from El-Salam strain of 30 weeks old were randomly divided into 6 groups with 3 replicates ( 10 hens +1 cock) each . The remaining 30 cocks were also divided into 6 groups of 5 cocks each and housed separately for semen evaluation experiment. The treatments were as follows, 1)

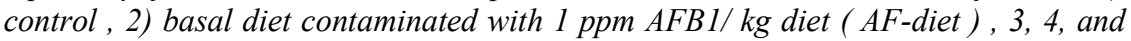
5) AF-diet supplemented with $0.1 \%, 0.25 \%$ and $0.4 \%$ humate, respectively and 6$)$ $A F$-diet supplemented with $0.5 \%$ hydrated sodium calcium aluminosilicate (HSCAS) . Birds were shifted to the experimental diets for 8 weeks (treated period) then they were fed on the basal diet without any supplementation for 4 weeks (recovery period). Results obtained can be summarized as follows: There was impairment of reproductive traits in form of decreasing fertility, hatchability of fertile eggs, chick weight at hatch and increasing chick abnormality rate in all aflatoxin groups. Also, semen characteristics like volume, concentration, mass motility were decreased and sperm abnormality and percentage of dead sperms were increased in aflatoxin groups. Also, there was impairment in serum biochemical parameters, antibodies titer against NDV for hen, posthatch chicks and egg yolk . aflatoxin B1 residual in egg yolk increased by AF- diet. Adding studied additives to aflatoxin diets diminished aflatoxicosis on all reproductive traits during treatment period and helped for recovering during recovery period.

Keyword: Aflatoxin, humate, aluminosilicate, prevention, laying hens

\section{INTRODUCTION}

Aflatoxins are a group of related toxic metabolic byproducts produced by Aspergillus flavus and other species of Aspergilli. A. flavus produces several aflatoxins, but aflatoxin $\mathrm{B}_{1}$ is the most important of the toxins (Giambrone et al., 1978). Aflatoxin (AF) (as mean total aflatoxins) is a relatively low molecular-weight, lipophilc molecule that appears to be absorbed rapidly (Kumagai, 1989) and completely (Wogan et al., 1967) from the gastrointestinal tract. The impairment of fertility and hatchability of fertile eggs by aflatoxicosis was found in local chicken

Issued by The Egyptian Society of Animal Production 
strains (Rizk et al., 1993) and in Japanese quail (Abd El-Hamid et al., 1992). On of the main causes for reducing fertility is the impairments in semen characteristics especially volume, concentration, mass motility and increasing sperm abnormality and dead caused by aflatoxicosis (Abdelhamid et al., 1995).

A variety of chemical, physical and biological techniques for mycotoxin decontamination of feeds have been used, but they have achieved limited success (Pitet, 1998). Absorbents used to prevent the gastrointestinal absorption of mycotoxins must form a strong complex and also have a high capacity to prevent saturation (Ramos and Hernendez, 1996). Aluminosilicats, activated charcoal and yeast products have been extensively studied with promising, but varying, results (Huwig, 2001). According to Decker and Corby (1980) activated charcoal absorbed at a rate of $10 \mathrm{mg}$ of $\mathrm{AFB}_{1} / \mathrm{g}$ whereas a gram of montmorillonite silicate was able to absorb only about $1 \mathrm{mg}$ of $\mathrm{AFB}_{1}$ at $\mathrm{pH} 7$ (Ramos and Hernandez, 1996). The term "humus" has been known to science for years, it is a transformation product of animal and plant organisms. Humate or humic acid (HA) is a class of compounds resulting from decomposition of organic matter and are natural constituents of drinking water, and lignite disintegrated compounds particularly from plants. They inhibit bacterial and fungal growth, thus decreasing levels of mycotoxins in feed (Stevenson, 1994). Its beneficial effects include stress management, immune system, anti-inflammatory activity, antiviral properties as well as prevention in of intestinal diseases mainly diarrhea in human and animals. The use of HA and related products in feed improved gut health for better nutrient utilization as well as improved the health status by working against pathogens developing immunity. Routine use of HA in feed improved growth of broilers by increasing the digestion of protein and improved trace element utilization. Research on humate includes humus, humic acid, fulvic acid, ulmic acid, and trace minerals (Islam et al., 2005). In recent years, it has been observed that humates included in the feed and water of poultry promoted growth. According to Van Rensburg et al. (2006) humic acid was able to absorb about 10.3, 7.4 and $11.9 \mathrm{mg}$ of $\mathrm{AFB}_{1} / \mathrm{g}$ of oxihumate at $\mathrm{pH} 3,5$ and 7 , respectively. They also described that humic acid, but not brewer's dried yeast could alleviate some of the toxic effects of aflatoxin in growing broilers. Sheng et al. (2009) Sodium humate has several advantages on AFB1 adsorption: i) higher affinity to AFB1; ii) not adsorb other nutrients; iii) the complex was very stable in different $\mathrm{pH}$ phosphate buffer.

Therefore, the purpose of the present study was to evaluate the possible preventive role of dietary absorbents on the productive performance of local laying hens given $\mathrm{AFB}_{1}(1 \mathrm{ppm})$.

\section{MATERIALS AND METHODS}

This study was carried out at Sakha Animal Production Research Station, Animal Production Research Institute, Agricultural Research Center, Ministry of Agriculture.

A total number of 180 hens plus 48 cocks from El-Salam strain of 30 weeks old were used. The birds divided into 6 groups ( 10 hens +1 cock each) and 3 replicates each and housed in floor pens ( $280 \mathrm{~cm}$ long x $220 \mathrm{~cm}$ wide). The remaining 30 cocks were also divided into 6 groups of 5 cocks of each and housed separately for semen evaluation. Birds were vaccinated against Newcastle disease virus ( NDV) Hitchener $\mathrm{B}_{1}$ at 7 day old, then Lasota vaccine at 18, 28 days old and 18 wks old they were 
vaccinated by oil vaccine. Basal diets were formulated to cover nutrient requirements (Table 1) according to Egyptian Feed Composition Table (2001). Laying hens were allotted for the following treatments:

1- The basal diet without any supplementation ( served as a control diet).

2- Basal diet supplemented with $1 \mathrm{ppm} \mathrm{AFB}_{1} / \mathrm{kg}$ diet (AF-diet).

3- AF-diet $+0.10 \%$ humate.

4- AF-diet $+0.25 \%$ humate.

5- AF-diet $+0.40 \%$ humate.

6- AF-diet $+0.50 \%$ HSCAS.

Table 1. Composition* and calculated analysis of local diet

\begin{tabular}{lc}
\hline Ingredients & \% \\
\hline Yellow corn & 64.0 \\
Soybean meal (44\%) & 24.78 \\
Wheat bran & 1.00 \\
Di-calcium phosphate & 1.61 \\
Limestone & 7.91 \\
DL-Methionine & 0.10 \\
Sodium chloride & 0.30 \\
Vit. \& Min. Mixture & 0.30 \\
\hline Total $\quad$ 100.00 \\
\hline Calculated analysis: & \\
Metabolizable energy (kcal/kg) & 2718 \\
Crude protein \% & 16.02 \\
Crude fiber \% & 3.46 \\
Crude fat \% & 2.96 \\
Calcium \% & 3.34 \\
Available phosphorus \% & 0.42 \\
Lysine \% & 0.89 \\
Methionine \% & 0.39 \\
Met. + Cystine \% & 0.66 \\
\hline
\end{tabular}

* As recommendation of Animal Production Research Institute, Agric. Res. Center

** Supplied per kg diet: Vit. A., $10000 \mathrm{IU}$; Vit. D3, $2000 \mathrm{IU}$; Vit. E $10 \mathrm{mg}$; Vit. K3, $1 \mathrm{mg}$; Vit. B1, $1 \mathrm{mg}$; Vit. B2, $5 \mathrm{mg}$; Vit. B6, $1.5 \mathrm{mg}$; Vit. B12, $10 \mathrm{mg}$; Niacin, $30 \mathrm{mg}$; Pantothenic acid, $10 \mathrm{mg}$; Folic acid, $1 \mathrm{mg}$; Biotin, $50 \mathrm{mg}$; Choline, $260 \mathrm{mg}$; Copper, $4 \mathrm{mg}$; Iron, $30 \mathrm{mg}$; Manganese, $60 \mathrm{mg}$; Zinc, $50 \mathrm{mg}$; Iodine, $1.3 \mathrm{mg}$; Selenium, $0.15 \mathrm{mg}$; Cobalt, $0.1 \mathrm{mg}$.

Experimental diets were fed for 8 weeks (treatment period) then they were fed basal diet free of any supplementation for another 4 weeks (recovery period). Characteristics were studied investigated during the $8^{\text {th }}$ and $12^{\text {th }}$ wk of the experiment. A total number of 900 eggs (50 eggs for each replicate) were set in incubator once a week (for three weeks in each period) to calculate the fertility and hatchability of fertile eggs percentages, hatched chicks were weighed. Five cocks from each treatment were used for collecting semen, by means of abdominal massage, at the end of treatment and recovery period. Semen volume was determined using graded tubes. Sperm concentration $\left(\times 10^{9}\right.$ sperm $\left./ \mathrm{ml}\right)$ was determined by a haemocytometer. Immediately after semen collection, sperm motility percentage was 
measured using a small droplet from each individual placed on a warm slide, covered with a slide and examined for sperm motility microscopically at $400 \times$ magnification using a stage warmer set at $39^{\circ} \mathrm{C}$. Sperm motility was classified as described by Melrose and Laing (1970). Sperm livability was determined (Lake and Stewart, 1978).

Blood samples were collected from 3 randombirds/treatment from the brachial vein in clean tubes without heparin at the end of treatment and recovery period. Serum was obtained by centrifugation the blood at $3000 \mathrm{rpm}$ for 20 minutes. Samples were then subjected to biochemical analysis using specific kits produced by Boehringer and Merck companies. Serum was submitted for determinations of uric acid, creatinine, cholesterol, triglycerides, aspartat amino transferase (AST), Alkaline phosphate (ALP) and gama-glutamyl transferase ( $\gamma \mathrm{GT})$ according to guidelines and recommendations of Bogin and Keller (1987). Biuret and Bromocresol green methods were used to determine total protein and albumin, respectively.

Glutathione peroxidase activity was determined in presence of reduced glutathione and Cumene-hydroperoxide as co-substrates using an end-point direct assay in liver and RBC haemolysate (Matkovics et al., 1988).

Malondialdehyde (MDA) was determined in blood by the thiobarbituric acid reaction method (Dorman et al., 1995). Serum calcium and phosphors concentration were determined by Inductively Coupled Plasma Atomic Emission Syetem (ICPAES).

Antibody titer against NDV was detected in layers and progeny sera at one day of posthatch chicks using method described by (Liu, 1999). Antibody was also detected in yolk samples at the end of treatment period.

At the end of treatment and recover periods three eggs from each treatment were taken to detect aflatoxin $B_{1}$ residue in yolk in National Research center, Mycotoxin Lab. according to Robert et al. (1982). At 8 and 12 weeks of age, total lipids and cholesterol in egg yolk extract were estimated by method of Weshburn and Nix (1974).

\section{Stability of AFB1 in contaminated eggs:}

Freshly laid eggs were collected and used within $48 \mathrm{hr}$ after collection. Whole egg were manually separated from the shell and mixed to obtain a suspension. The suspensions was heated up to $100^{\circ} \mathrm{C}$ for $5,10,15$ and 20 minutes using controlled water bath Dual Chamber 5/10 L Model 28 L, Catalogue No. 040661 according to Fabien and Ulrich (2007). The suspension was previously tested for aflatoxin $\mathrm{B}_{1}$ with a mean value of $0.890 \mu \mathrm{g} / \mathrm{kg}$. The suspension was then extracted and quantified using ELISA test.

\section{Aflatoxin production:}

Aflatoxin was produced via fermentation of rice by Aspergillus parasiticus NRRL 2999 as described by Shotwell et al. (1966) and modified by West et al. (1973). Fermented rice was autoclaved, dried and ground to fine powder which was analyzed spectrophotometrically for its aflatoxin content by method of Nabney and Nesbitt (1965) which modified by Wiseman et al. (1967). Aflatoxin in the rice powder were extracted by chloroform then incorporated into the basal diet and confirmed by HPLC to provide the desired level $1 \mathrm{ppm}$ aflatoxin $\mathrm{B}_{1}$. 


\section{Humate and HSCAS composition:}

Biofarm ${ }^{\circledR}$ Dry, totally natural humate was purchased from Farmavet International Istnbul-Turkey. Each $\mathrm{kg}$ of humate contained $160 \mathrm{mg}$ polymeric polyhydroxy acid (humic, fulvic, ulmic and humatomelanic acids), 663.3 Sio2 and other minerals (Mn, 50 mg; Zn, 60 mg; Fe, 60 mg; Cu, 5 mg; Co, 0.2 mg; I, $1 \mathrm{mg}$; Se, $0.5 \mathrm{mg}$ and $\mathrm{Al}, \mathrm{Na}, \mathrm{K}, \mathrm{Mg}$ and $\mathrm{P}$ in trace amounts).

Hydrated sodium calcium aluminosilicate (HSCAS) is a chemical compound that containing Silica, 64.70\%; Aluminum, 15.50\%; Iron, 1.75\%; Calcium, $1.26 \%$; Potasium, 1.80\%; Sodium, 2.55\% and Magnesium, 1.54\% and moisture $10.9 \%$ provided from Integrated World Enterprises Co. USA.

\section{Protection percentage :}

For any parameter studied, to compare the anti-aflatoxic effects achieved by the different agents studied, a protection percentage was calculated as follows;

Protection percentage $=\begin{array}{cc}\text { X - Y } \\ \text {------------- } \\ \text { Y }\end{array}$

Where, $\mathrm{X}=$ change of AF- group ( $\mathrm{T} 2$ ) from control ( T1),

And $\mathrm{Y}=$ change of any other group ( T3, ------- T6) from control .

\section{Statistical analysis:}

Data were subjected to one way analysis of variance using the General Linear Model of SASR software (SAS, 1994). Before analysis, all percentages were subjected to $\operatorname{logarithmic}$ or arcsine values transformation $(\log 10 \mathrm{x}+1)$ to approximate normal distribution. Significant differences among treatment means $(P \leq 0.05)$ were separated by Duncan's new multiple range test (Duncan, 1955).

The following model was used to study the effect of some feed additives (humate or hydrated sodium calcium aluminosilicate with aflatoxin) on parameters investigated as follows:

Where

$$
\mathrm{Yij}=\mu+\mathrm{Ti}+\mathrm{eij}
$$

$\mathrm{Yij}=$ an observation

$\mu=$ overall mean

$\mathrm{Ti}=$ effect of the factor studied $(\mathrm{I}=1,2 \ldots$ and 6$)$

eij= residual " random error "

\section{RESULTS AND DISCUSSION}

\section{Reproductive performance:}

There was a significant effect for decreasing fertility, hatchability and chick weight at hatch and increasing chick abnormalities by aflatoxin diets without or with additives for local hen after 8 weeks of treatment period (Table 2). These results agree with those obtained by Qureshi et al. (1998) who found that AF dietary exposure resulted in embryonic mortality and reduction in hatchability compared to control. Also, Sur and Celik (2003) indicated that low concentration of AFB1 transferred into the fertilized eggs might be the cause of serious problems. The 
reduction in fertility rates in the present study may be due to impaired semen characteristics in this study while increasing total death of embryos during the hatching period may explain the reduction in hatchability of fertile eggs. This interference may be attributed to initial effects of aflatoxin upon the gonads (Abd ElHamid, 1992). In addition to a rapid, direct effect of aflatoxin on hatchability , another attractive hypothesis might be an inadequate or altered chemical composition of the egg itself. Changes in the hen's protein, carbohydrate and lipid metabolism occur rapidly after feeding dietary aflatoxin. Such alterations in metabolism could alter the chemical composition of the egg and its subsequent hatchability. Both humate and HSCAS had a protective effect of reproductive traits against aflatoxin diets during treatment period (Table 2) and they were helped for recovery of all reproductive traits. Protections of reproductive performance by $0.25 \%$ and $0.40 \%$ humate were $(71.44,66.57,63.08$ and $66.15 \%)$ and $(65.12,67.30,51.31$ and $63.89 \%$ ), while that by $0.5 \%$ HSCAS were $(51.53,46.69,43.68$ and $38.68 \%$ ) for fertility, hatchability, abnormality $\%$ and chick weight at hatch, respectively, against $1 \mathrm{ppm} \mathrm{AFB}_{1} / \mathrm{kg}$ diet. After 4 weeks recovery period, almost aflatoxin groups continued to be affected but at less severity for all reproductive traits (Table 2).

Table 2. Reproductive traits of EI-Salam strain during treatment and recovery period as affected by aflatoxin diets without and with additives tested

\begin{tabular}{|c|c|c|c|c|c|c|c|}
\hline \multirow[b]{2}{*}{ Items } & \multirow[b]{2}{*}{ Control } & \multirow[b]{2}{*}{ AF-diet } & \multicolumn{4}{|c|}{ AF-diet + } & \multirow[b]{2}{*}{ SEM } \\
\hline & & & $\begin{array}{c}0.1 \% \\
\text { humate }\end{array}$ & $\begin{array}{c}0.25 \% \\
\text { humate }\end{array}$ & $\begin{array}{c}0.4 \% \\
\text { humate }\end{array}$ & $\begin{array}{c}0.5 \% \\
\text { HSCAS }\end{array}$ & \\
\hline \multicolumn{8}{|c|}{ Treatment period } \\
\hline Fertility, \% & $88.31^{\mathrm{a}}$ & $78.82^{\mathrm{d}}$ & $80.20^{\mathrm{cd}}$ & $85.60^{b}$ & $85.00^{b}$ & $83.71^{c}$ & 0.257 \\
\hline Hatchability, \% & $81.52^{\mathrm{a}}$ & $70.45^{\mathrm{e}}$ & $73.58^{\mathrm{d}}$ & $77.82^{\mathrm{b}}$ & $77.90^{\mathrm{b}}$ & $75.62^{c}$ & 0.197 \\
\hline Abnormality, \% & $1.351^{\mathrm{d}}$ & $2.460^{\mathrm{a}}$ & $1.981^{\mathrm{b}}$ & $1.622^{\mathrm{c}}$ & $1.730^{\mathrm{c}}$ & $1.811^{\mathrm{b}}$ & 0.034 \\
\hline $\begin{array}{l}\text { Chick weight at } \\
\text { hatch }(\mathrm{g})\end{array}$ & $31.90^{\mathrm{a}}$ & $28.80^{\mathrm{d}}$ & $28.92^{\mathrm{c}}$ & $30.85^{\mathrm{b}}$ & $30.78^{b}$ & $30.00^{\mathrm{bc}}$ & 0.248 \\
\hline \multicolumn{8}{|c|}{ Recovery period } \\
\hline Fertility, \% & $89.21^{\mathrm{a}}$ & $83.20^{c}$ & $84.60^{c}$ & $87.50^{b}$ & $87.00^{b}$ & $86.80^{b}$ & 0.231 \\
\hline Hatchability, \% & $81.68^{\mathrm{a}}$ & $77.53^{c}$ & $77.91^{\mathrm{c}}$ & $80.03^{b}$ & $80.10^{\mathrm{b}}$ & $78.81^{\mathrm{c}}$ & 0.251 \\
\hline Abnormality, $\%$ & $1.283^{\mathrm{d}}$ & $1.631^{\mathrm{a}}$ & $1.583^{\mathrm{b}}$ & $1.371^{\mathrm{c}}$ & $1.370^{\mathrm{c}}$ & $1.420^{\mathrm{bc}}$ & 0.049 \\
\hline $\begin{array}{l}\text { Chick weight at } \\
\text { hatch }(\mathrm{g})\end{array}$ & $32.0^{\mathrm{a}}$ & $30.17^{b}$ & $30.43^{\mathrm{b}}$ & $31.25^{\mathrm{a}}$ & $31.12^{\mathrm{a}}$ & $31.00^{\mathrm{ab}}$ & 0.230 \\
\hline
\end{tabular}

\section{Semen characteristics:}

AS illustrated in Table (3) aflatoxin containing diets caused a significant $(\mathrm{P}<0.05)$ decrease in semen volume, sperm concentration and mass motility as well as the percentages of sperm abnormalities and dead sperms. These results are in harmony with those obtained by Sharlin et al. (1980); Clarke et al. (1986) and Abdelhamid et al. (1995). The significant decline in semen volume and its concentration due to feeding AF-diets was attributed to the impair spermatogenesis resulting from decreased feed consumption which caused reduction in $\mathrm{LH}$ and therefore reduce 
testosterone level (Sharlin et al., 1981). Mohiddin (1982) have implied that AF caused degeneration and a decrease in germinal epithelial cells, disruption in spermatogenesis. Also, Ortatatli et al. (2002) showed that AF might totally or partially (dose related) suppresses spermatogenesis testes. On the other hand, Muthiah et al. (1997) found that graded levels of sperm motility and concentration but the incidence of abnormal spermatozoa increased with the aflatoxin content of the diet. The severity of aflatoxin effect on semen characteristics were decreased by adding the studied additives to aflatoxin diets (Table 3). Protections of semen characteristics by $0.25 \%$ and $0.40 \%$ humate were $(70.33,78.11,76.76,73.78$ and $67.02 \%)$ and $(63.22,63.28,69.00,82.07$ and $63.22 \%)$, while that by $0.5 \%$ HSCAS were $(55.48,37.28,58.95,57.64$ and $42.29 \%$ ) for volume, concentration, mass motility, abnormality and dead sperm \%, respectively, against $1 \mathrm{ppm} \mathrm{AFB}_{1} / \mathrm{kg}$ diet. After 4 weeks recovery period, alterations caused by aflatoxin diets were negated for semen volume, sperm concentration and mass motility and to an extent diminished for sperm abnormality and dead sperms (Table 3).

Table 3. Semen evaluation of El-Salam strain at the end of treatment and recovery period as affected by aflatoxin diets without and with additives tested

\begin{tabular}{|c|c|c|c|c|c|c|c|}
\hline \multirow[b]{2}{*}{ Items } & \multirow[b]{2}{*}{ Control } & \multirow[b]{2}{*}{ AF-diet } & \multicolumn{4}{|c|}{ AF-diet + } & \multirow[b]{2}{*}{ SEM } \\
\hline & & & $\begin{array}{c}0.1 \% \\
\text { humate }\end{array}$ & $\begin{array}{c}0.25 \% \\
\text { humate }\end{array}$ & $\begin{array}{c}0.4 \% \\
\text { humate }\end{array}$ & $\begin{array}{c}0.5 \% \\
\text { HSCAS }\end{array}$ & \\
\hline \multicolumn{8}{|c|}{ Treatment period } \\
\hline Volume, $\mathrm{ml}$ & $0.465^{\mathrm{a}}$ & $0.310^{\mathrm{d}}$ & $0.336^{\mathrm{c}}$ & $0.419^{b}$ & $0.408^{b}$ & $0.396^{\mathrm{b}}$ & 0.009 \\
\hline Concentration, $10^{9} / \mathrm{ml}$ & $3.802^{\mathrm{a}}$ & $2.925^{\mathrm{d}}$ & $3.00^{\mathrm{d}}$ & $3.610^{\mathrm{b}}$ & $3.480^{\mathrm{bc}}$ & $3.252^{\mathrm{c}}$ & 0.010 \\
\hline Mass motility, $\%$ & $83.75^{\mathrm{a}}$ & $66.81^{\mathrm{e}}$ & $70.15^{\mathrm{d}}$ & $79.81^{\mathrm{b}}$ & $78.50^{\mathrm{b}}$ & $76.80^{\mathrm{c}}$ & 0.66 \\
\hline Abnormality, $\%$ & $7.50^{\mathrm{e}}$ & $15.21^{\mathrm{a}}$ & $11.30^{\mathrm{b}}$ & $8.65^{\mathrm{c}}$ & $8.25^{\mathrm{c}}$ & $9.55^{\mathrm{d}}$ & 0.19 \\
\hline Dead, $\%$ & $2.25^{\mathrm{e}}$ & $9.30^{\mathrm{a}}$ & $4.45^{\mathrm{b}}$ & $2.80^{\mathrm{d}}$ & $3.12^{\mathrm{d}}$ & $4.00^{c}$ & 0.22 \\
\hline \multicolumn{8}{|c|}{ Recovery period } \\
\hline Volume, $\mathrm{ml}$ & $0.459^{\mathrm{a}}$ & $0.335^{\mathrm{c}}$ & $0.386^{\mathrm{bc}}$ & $0.438^{\mathrm{ab}}$ & $0.413^{b}$ & $0.400^{\mathrm{b}}$ & 0.007 \\
\hline Concentration, $10^{9} / \mathrm{ml}$ & $3.81^{\mathrm{a}}$ & $3.12^{\mathrm{b}}$ & $3.43^{\mathrm{b}}$ & $3.69^{\mathrm{ab}}$ & $3.55^{\mathrm{b}}$ & $3.72^{\mathrm{ab}}$ & 0.011 \\
\hline Mass motility, $\%$ & $84.5^{\mathrm{a}}$ & $82.4^{\mathrm{b}}$ & $83.3^{\mathrm{b}}$ & $84.6^{\mathrm{a}}$ & $83.9^{\mathrm{a}}$ & $84.0^{\mathrm{a}}$ & 0.71 \\
\hline Abnormality, $\%$ & $7.31^{\mathrm{d}}$ & $10.25^{\mathrm{a}}$ & $8.81^{\mathrm{b}}$ & $8.61^{\mathrm{c}}$ & $7.90^{\mathrm{c}}$ & $8.00^{\mathrm{c}}$ & 0.17 \\
\hline Dead, $\%$ & $2.75^{\mathrm{c}}$ & $5.52^{\mathrm{a}}$ & $4.80^{\mathrm{b}}$ & $3.00^{\mathrm{c}}$ & $3.16^{\mathrm{c}}$ & $3.08^{\mathrm{c}}$ & 0.15 \\
\hline
\end{tabular}

$\mathrm{a}, \mathrm{b} . .$. and e: Mean in the same row with different letters are differ significantly at $\mathrm{P} \leq 0.05$.

SEM: Standard error of the mean.

Blood biochemical parameters:

Results presented in Table (4) show that serum concentration of total protein and albumin were significantly reduced $(\mathrm{P}<0.05)$ in birds fed diet contaminated with 1 ppm $\mathrm{AFB}_{1} / \mathrm{kg}$ diet by 24.74 and $33.91 \%$ respectively when compared with the control birds. One of the primary toxic effects of aflatoxin is the rapid inhibition of protein synthesis in the liver as that obtained by Safamher and Shivazad (2005).

Uric acid is the primary product of nitrogen catabolism in chicken and excreted by the kidney. From Table (4), it can be seen that serum level of uric acid was significantly elevated $(\mathrm{P}<0.05)$ when the birds fed diet contained with 1 ppm $\mathrm{AFB}_{1} / \mathrm{kg}$ by $46.1 \%$, compared with the control. Also, the serum level of creatinine 
was significantly increased $(\mathrm{P}<0.05)$ with AF-diet by $33.33 \%$, compared with the control. At the same time, the results herein are similar with of Kubena et al. (1995) and Abdel-Maksoud et al. (2002) who suggested incidence of kidney damage and impaired renal function due to the nephrotoxic effect of aflatoxin.

Table 4. Some blood parameters at the end of treatment period as affected by aflatoxin diets without and with additives tested

\begin{tabular}{|c|c|c|c|c|c|c|c|}
\hline \multirow[b]{2}{*}{ Items } & \multirow[b]{2}{*}{ Control } & \multirow[b]{2}{*}{ AF-diet } & \multicolumn{4}{|c|}{ AF-diet + } & \multirow[b]{2}{*}{ SEM } \\
\hline & & & $\begin{array}{c}0.1 \% \\
\text { humate }\end{array}$ & $\begin{array}{c}0.25 \% \\
\text { humate }\end{array}$ & $\begin{array}{c}0.4 \% \\
\text { humate }\end{array}$ & $\begin{array}{c}\mathbf{0 . 5 \%} \% \\
\text { HSCAS }\end{array}$ & \\
\hline T. protein, $\mathrm{g} / 100 \mathrm{ml}$ & $3.80^{\mathrm{a}}$ & $2.86^{\mathrm{d}}$ & $3.10^{\mathrm{c}}$ & $3.55^{\mathrm{ab}}$ & $3.48^{\mathrm{ab}}$ & $3.36^{\mathrm{b}}$ & 0.052 \\
\hline Albumin, $\mathrm{g} / 100 \mathrm{ml}$ & $2.30^{\mathrm{a}}$ & $1.52^{\mathrm{d}}$ & $1.73^{\mathrm{c}}$ & $2.10^{\mathrm{ab}}$ & $2.15^{\mathrm{ab}}$ & $2.00^{\mathrm{b}}$ & 0.046 \\
\hline $\mathrm{AST}, \mathrm{IU} / \mathrm{L}$ & $88.0^{\mathrm{c}}$ & $117.0^{\mathrm{a}}$ & $100.0^{\mathrm{ab}}$ & $93.5^{\mathrm{b}}$ & $94.0^{\mathrm{b}}$ & $96.3^{\mathrm{b}}$ & 1.28 \\
\hline ALT, IU/L & $45.28^{\mathrm{c}}$ & $60.13^{\mathrm{a}}$ & $53.51^{\mathrm{ab}}$ & $48.21^{\mathrm{b}}$ & $49.50^{\mathrm{b}}$ & $50.6^{\mathrm{b}}$ & 1.05 \\
\hline$\gamma \mathrm{GT}, \mathrm{IU} / \mathrm{L}$ & $39.10^{\mathrm{d}}$ & $68.0^{\mathrm{a}}$ & $55.5^{\mathrm{b}}$ & $45.8^{c}$ & $46.20^{\mathrm{c}}$ & $50.6^{\mathrm{bc}}$ & 0.76 \\
\hline Triglyceride, $\mathrm{mg} / 100 \mathrm{ml}$ & $120.0^{\mathrm{a}}$ & $90.0^{\mathrm{d}}$ & $99.8^{\mathrm{c}}$ & $109.6^{\mathrm{b}}$ & $108.0^{\mathrm{b}}$ & $105.0^{\mathrm{b}}$ & 1.58 \\
\hline Cholesterol, $\mathrm{mg} / 100 \mathrm{ml}$ & $138.8^{\mathrm{a}}$ & $98.4^{\mathrm{d}}$ & $110.5^{\mathrm{c}}$ & $126.8^{b}$ & $121.0^{\mathrm{b}}$ & $118.5^{b c}$ & 1.76 \\
\hline ALP, IU/L & $160.0^{\mathrm{d}}$ & $196.0^{\mathrm{a}}$ & $178.8^{\mathrm{b}}$ & $170.5^{\mathrm{c}}$ & $171.3^{\mathrm{c}}$ & $173.6^{\mathrm{c}}$ & 1.53 \\
\hline Uric acid, $\mathrm{mg} / 100 \mathrm{ml}$ & $4.50^{\mathrm{d}}$ & $8.35^{\mathrm{a}}$ & $6.25^{\mathrm{b}}$ & $5.18^{\mathrm{c}}$ & $5.11^{\mathrm{c}}$ & $6.00^{\mathrm{b}}$ & 0.22 \\
\hline Creatine, $\mathrm{mg} / 100 \mathrm{ml}$ & $15.0^{\mathrm{cd}}$ & $22.5^{\mathrm{a}}$ & $20.15^{\mathrm{b}}$ & $16.81^{\mathrm{c}}$ & $16.96^{\mathrm{c}}$ & $17.00^{\mathrm{c}}$ & 0.76 \\
\hline GSH-Px, rbc $\mu \mathrm{g} / \mathrm{g}$ protein & $21.0^{\mathrm{a}}$ & $16.0^{\mathrm{d}}$ & $17.22^{\mathrm{c}}$ & $19.52^{b}$ & $19.10^{\mathrm{b}}$ & $18.50^{\mathrm{bc}}$ & 0.31 \\
\hline $\mathrm{MAD}, \mathrm{mmol} / \mathrm{L}$ & $6.02^{\mathrm{c}}$ & $8.10^{\mathrm{a}}$ & $8.00^{\mathrm{a}}$ & $6.48^{\mathrm{bc}}$ & $6.59^{\mathrm{bc}}$ & $7.10^{\mathrm{b}}$ & 0.16 \\
\hline $\mathrm{Ca}, \mathrm{g} / 100 \mathrm{ml}$ & $11.10^{\mathrm{a}}$ & $6.80^{\mathrm{d}}$ & $8.35^{\mathrm{c}}$ & $10.0^{\mathrm{b}}$ & $9.80^{\mathrm{b}}$ & $9.05^{\mathrm{bc}}$ & 0.21 \\
\hline $\mathrm{P}, \mathrm{g} / 100 \mathrm{ml}$ & $5.51^{\mathrm{a}}$ & $3.38^{\mathrm{d}}$ & $4.46^{\mathrm{c}}$ & $4.88^{\mathrm{b}}$ & $4.76^{\mathrm{b}}$ & $4.56^{\mathrm{bc}}$ & 0.17 \\
\hline Yolk choleste & $14.5^{\mathrm{a}}$ & $10.82^{\mathrm{d}}$ & $11.72^{\mathrm{c}}$ & $12.49^{\mathrm{b}}$ & $12.09^{\mathrm{b}}$ & $12.30^{\mathrm{b}}$ & 0.29 \\
\hline Yolk total lipids ( $\mathrm{mg} / \mathrm{g}$ ) & $232.87^{\mathrm{a}}$ & $201.55^{\mathrm{c}}$ & $215.32^{\mathrm{b}}$ & $223.11^{\mathrm{b}}$ & $220.5^{\mathrm{b}}$ & $218.12^{\mathrm{b}}$ & 4.75 \\
\hline
\end{tabular}

a, b... and d: Mean in the same row with different letters are differ significantly at $\mathrm{P} \leq 0.05$. SEM: Standard error of the mean.

Serum triglycerides and cholesterol concentrations were significantly decreased $(\mathrm{P}<0.05)$ in birds fed AF-diet compared with the control. Our results in this respect are agreement in part with that of Weibking et al. (1994). Abo-Norag et al. (1995) and Kubena et al. (1995) who suggested general reduction in lipogenesis inhibition of cholesterol biosynthesis and impaired lipid transport with $\mathrm{AFB}_{1}$. From Table (4) it can be seen also that serum activities of ALT and AST and gama-glutamyl transferase $\gamma \mathrm{GT}$ as well as ALP were significantly increased $(\mathrm{P}<0.05)$ with $\mathrm{AFB}_{1}$ treatment when compared with the control. Serum activities of aspartat amino transferase (AST), alkaline phosphate (ALP) and gama-glutamyl transferase ( $\gamma \mathrm{GT}$ ) may be useful test for liver disease in birds. While, the enzyme $\gamma \mathrm{GT}$ is a membranelocalized enzyme that plays a major role in glutathione metamolism and resorption of amino acid from the glomerular filterate (Ebeid et al., 2005). Shukla and Pocthauri (1995) attributed the change in concentration of serum enzymes resulting from continued administration of aflatoxin to severe cellular damage. This may be in the 
form of necrosis or some other modification leading to increased cellular permeability which in turn results in the release of enzyme into the serum.

Adding the studied additives decreased the severity of aflatoxin diets effects for all blood parameters. Protections of blood parameters by $0.25 \%$ and $0.40 \%$ humate were $(73.4,74.34,71.54,65.36,70.28,75.38,76.28,65.58$ and $66.68 \%)$ and $(65.97$, $80.77,74.10,60.00,55.96,65.47,74.26,63.84$ and $64.13 \%$ ), while that by $0.5 \%$ HSCAS were $(53.19,61.55,45.77,50.00,49.74,57.45,65.23,46.52$ and $57.38 \%)$ for total protein, albumin, uric acid, triglycerides, cholesterol, ALT, AST, $\gamma \mathrm{GT}$ and $\mathrm{ALP}$, respectively, against $1 \mathrm{ppm} \mathrm{AFB}_{1} / \mathrm{kg}$ diet.

Gluthionine peroxidase (GSH-Px), however, plays an important role in eliminating free radicals and preventing lipid peroxidation in tissue. Regarding the data in Table (4), indicated that (GSH-Px) activity in blood was significantly reduced $(\mathrm{P}<0.05)$ in birds fed AF-diet. The decrease was $23.80 \%$ in the blood with $\mathrm{AFB}_{1}$ less than the corresponding values of the control. This reduction was concomitant by a significant increase in the Malondialdehyde content (MDA) in blood as shown in Table (4). As expected, the level of $\mathrm{AFB}_{1}$ resulted in an accumulating increase of blood MDA by $25.92 \%$ compared with the control. This inhibition in (GSH-Px) activity may be caused by a greater degradation rate of blood (GSH-Px) with reduced the rate of synthesis within the liver or a reduced rate of secretion. In conclusion, aflatoxin may inhibit the (GSH-Px) activity as well as decrease the ability to scavenge oxygen free radicals directly or indirectly, which stimulates lipid peroxidation due to an increase of free radical generation as measured by (MDA) production. These results are in agreement with Hoehler and Marquardt (1996) in chicken. Moreover, Shen et al. (1994) showed that $\mathrm{AFB}_{1}$ causes lipid peroxidation in rat.

The effect of $\mathrm{AFB}_{1}$ on the serum level of calcium and inorganic phosphors are shown in Table (4). Data showed that serum level of calcium was significantly decreased by $38.18 \%$ in the AF-diet, compared with the control group. Also, corresponding serum level of inorganic phosphors was significantly decrease $(\mathrm{P}<0.05)$ by $38.55 \%$. The lower concentration of serum inorganic phosphors may be due to reducing renal reabsorption or inhibition of tubular phosphate secretion and/or decreased intestinal absorption of phosphorus, meanwhile, the decrease in serum calcium level may be due to the impaired of gastrointestinal absorption and increased urinary excretion (El-Sebai, 2005).

Adding humate $(0.25$ or $0.40 \%)$ and HSCAS to aflatoxin diets diminished the severity effects of aflatoxin diets on serum constituents (Table 4). Also, Qota et al. (2005) found similar results by adding $0.5 \%$ HSCAS to aflatoxin diets. Van Rensburg et al. (2006) found that some serum constituents were returned to control value when oxihumate as used with aflatoxin exposed chickens. Protections of GSHPx, MDA, calcium and phosphors by 0.25 and $0.40 \%$ humate were $(70.38,71.41$, 76.16 and $70.77 \%$ ) and $(62.01,65.47,71.42$ and $65.11 \%$ ), while those by $0.5 \%$ HSCAS were $(50.00,40.23,53.56$ and $55.67 \%$ ), respectively. The hens fed AF-diet recorded value of yolk cholesterol and total lipids which were found to be lower than the other treatments and these may be as a result to the inhibition of cholesterol biosynthesis (Table 4). In this respect, Kato et al. (1969) demonstrated for AF inhibitor of cholesterol biosynthesis in rats. Adding humate and HSCAS to aflatoxin diets increased yolk cholesterol and total lipids. After 4 weeks recovery period, the 
same alterations of treatment were continued (but less severity) especially for group fed aflatoxin without additives (Table 5).

Humate supplementation of AF-diets significantly improved serum constituent values, probably as a result of effective adsorption in the gut to reduce the amount of aflatoxin absorption by the body.

Table 5. Some blood parameters at the end of recovery period as affected by aflatoxin diets without and with additives tested

\begin{tabular}{lccccccc}
\hline & & & \multicolumn{5}{c}{ AF-diet +} \\
\cline { 3 - 7 } \multicolumn{1}{c}{ Items } & Control AF-diet & $\begin{array}{c}\mathbf{0 . 1 \%} \\
\text { humate }\end{array}$ & $\begin{array}{c}\mathbf{0 . 2 5 \%} \\
\text { humate }\end{array}$ & $\begin{array}{c}\mathbf{0 . 4 \%} \\
\text { humate }\end{array}$ & $\begin{array}{c}\mathbf{0 . 5 \%} \\
\text { HSCAS }\end{array}$ & SEM \\
\hline T. protein, g/100 ml & 3.80 & 3.30 & 3.40 & 3.70 & 3.76 & 3.70 & 0.05 \\
$\gamma$ GT, IU/L & $39.10^{\mathrm{d}}$ & $58.00^{\mathrm{a}}$ & $53.20^{\mathrm{b}}$ & $43.00^{\mathrm{c}}$ & $44.00^{\mathrm{c}}$ & $48.20^{\mathrm{bc}}$ & 0.83 \\
Cholesterol, mg/100 ml & $138.8^{\mathrm{a}}$ & $100.0^{\mathrm{d}}$ & $118.5^{\mathrm{c}}$ & $122.8^{\mathrm{b}}$ & $120.6^{\mathrm{b}}$ & $116.5^{\mathrm{bc}}$ & 1.63 \\
Creatine, mg/100 ml & $15.00^{\mathrm{b}}$ & $19.00^{\mathrm{a}}$ & $18.35^{\mathrm{a}}$ & $15.78^{\mathrm{b}}$ & $16.41^{\mathrm{b}}$ & $16.00^{\mathrm{b}}$ & 0.82 \\
MAD, mmol/L & $6.00^{\mathrm{c}}$ & $7.80^{\mathrm{a}}$ & $7.50^{\mathrm{a}}$ & $6.60^{\mathrm{b}}$ & $6.75^{\mathrm{b}}$ & $7.00^{\mathrm{b}}$ & 0.15 \\
Ca, g/100 ml & $11.00^{\mathrm{a}}$ & $9.11^{\mathrm{b}}$ & $9.25^{\mathrm{b}}$ & $10.83^{\mathrm{a}}$ & $11.00^{\mathrm{a}}$ & $10.80^{\mathrm{a}}$ & 0.18 \\
$\mathrm{P}, \mathrm{g} / 100 \mathrm{ml}$ & $5.50^{\mathrm{a}}$ & $4.85^{\mathrm{b}}$ & $4.93^{\mathrm{b}}$ & $5.20^{\mathrm{a}}$ & $5.18^{\mathrm{a}}$ & $5.08^{\mathrm{a}}$ & 0.14 \\
Yolk cholesterol ( mg/g) & $14.31^{\mathrm{a}}$ & $11.95^{\mathrm{c}}$ & $12.88^{\mathrm{b}}$ & $13.45^{\mathrm{ab}}$ & $12.91^{\mathrm{b}}$ & $12.96^{\mathrm{b}}$ & 0.35 \\
Yolk total lipids ( mg/g) & $233.4^{\mathrm{a}}$ & $219.8^{\mathrm{c}}$ & $224.4^{\mathrm{b}}$ & $228.6^{\mathrm{ab}}$ & $226.4^{\mathrm{ab}}$ & $227.1^{\mathrm{ab}}$ & 5.23 \\
\hline
\end{tabular}

a, b.... and d: Mean in the same row with different letters are differ significantly at $\mathrm{P} \leq 0.05$.

SEM: Standard error of the mean.

The data represented in Table (6) showed that AF-diet gave the lowest serum and yolk NDV antibodies titer as compared to the other treatment groups at the end of treatment period. However, these results indicated that may be we can depend on, and use yolk to measure the antibodies titer, as the immune level of the birds, since the collection of eggs are more easily than collection of serum, also were save for birds. Adding the studies additives decreased the severity of aflatoxin diets effects for NDV antibodies. Also, serum antibodies titer of posthatch chicks increased with increase the level of the antibodies titer in there mothers or/and in the eggs laid from layers fed studied additives compared with layers fed AFB1 without additives . Embryonic exposure via maternal transfer of AF residues or metabolities may affect the differentiation and maturation process of immature progenitor cells, which is considered crucial for the establishment of various hematopoietic lineage cells such as lymphocytes and macrophages (Nicolas-Bolnet et al., 1995). Present findings show that humic acid significantly $(\mathrm{P}<0.05)$ ameliorated the adverse effect of AF on the humoral immunity against ND. Humic acid has been known to bind to the AF 
molecules in gastrointestinal tract and precluding their absorption that can alleviate the toxicity of AF in poultry (Van Rensburg et al., 2006).

Table 6. Antibodies titer against NDV of hen, yolk and progeny at a day of hatch affected by aflatoxin diets without and with additives tested

\begin{tabular}{lccccccc}
\hline \multirow{2}{*}{ Items } & Control & \multirow{2}{*}{$\begin{array}{c}\text { AF- } \\
\text { diet }\end{array}$} & $\begin{array}{c}\mathbf{0 . 1 \%} \\
\text { humate }\end{array}$ & $\begin{array}{c}\mathbf{0 . 2 5} \text { humate } \\
\text { hum }\end{array}$ & $\begin{array}{c}\mathbf{0 . 4 \%} \\
\text { humate }\end{array}$ & $\begin{array}{c}\mathbf{0 . 5} \% \\
\text { HSCAS }\end{array}$ & SEM \\
\hline Serum hen at 38 wks & $7.50^{\mathrm{a}}$ & $5.48^{\mathrm{d}}$ & $5.92^{\mathrm{d}}$ & $6.70^{\mathrm{bc}}$ & $6.81^{\mathrm{b}}$ & $6.25^{\mathrm{c}}$ & 0.05 \\
Yolk egg at 38 wks & $9.60^{\mathrm{a}}$ & $7.28^{\mathrm{c}}$ & $7.96^{\mathrm{c}}$ & $8.90^{\mathrm{b}}$ & $8.75^{\mathrm{b}}$ & $8.15^{\mathrm{bc}}$ & 0.08 \\
Post-hatch chick & $6.00^{\mathrm{a}}$ & $5.27^{\mathrm{c}}$ & $5.69^{\mathrm{b}}$ & $5.86^{\mathrm{a}}$ & $5.80^{\mathrm{a}}$ & $5.72^{\mathrm{ab}}$ & 0.04 \\
\hline
\end{tabular}

a, b.... and d: Mean in the same row with different letters are differ significantly at $\mathrm{P} \leq 0.05$.

SEM: Standard error of the mean.

Aflatoxin B1 residue was found in egg yolk of hens fed AF-diets without or with studies additives are presented in Table (7). There was significant differences between experimental treatments and the hens fed AF-diet recorded the highest value $(0.890 \mu \mathrm{g} / \mathrm{kg})$, while there were no residues in egg yolk of hens fed the control diet. In this respect, Oliveira et al. (2000) found that residues of $\mathrm{AFB}_{1}$ were detected only in the eggs of hens given $500 \mu \mathrm{g} / \mathrm{kg}$ feed at levels that ranged from 0.05 to 0.16 $\mu \mathrm{g} / \mathrm{kg}$ and indicated that the feed: egg AFB1 transmission ratio was approximately equals to 5000:1. With laying Japanese quails, was 3333:1 for diet containing $100 \mu \mathrm{g}$ $\mathrm{AFB}_{1} / \mathrm{kg}$ feed. In this study the hens fed AF-diet recovery value which was found to be higher compared to those found in the literature and this may be due to higher doses of $\mathrm{AFB}_{1}$ and lower egg production in the local hens and consequently increased the level of $\mathrm{AFB}_{1}$ excreted in the egg. However, Rizk et al. (1993) and Ali et al. (2006) found with local hen fed AF-diet containing $200 \mathrm{ppb}$ and $1000 \mathrm{ppb}$ that $\mathrm{AFB}_{1}$ residue being 1.98 an $1.22 \mathrm{ppb}$ in the egg, respectively. The addition of humate or HSCAS to AF-diet decreased AFB1 residue in egg yolk. After 4 weeks of recovery period, there were no residues in egg yolk. These results are in agree with those obtained by Wolzak et al. (1985) who found that no residues were detected in the albumen or yolk after 5 and 7 days of withdrawal, respectively.

Table 7. AFB-1 residue in egg yolk $(\mu \mathrm{g} / \mathrm{kg})$ at the end of treatment period as affected by aflatoxin diet

\begin{tabular}{cccccccc}
\hline \multirow{2}{*}{ Items } & Control & \multirow{2}{*}{$\begin{array}{c}\text { AF- } \\
\text { diet }\end{array}$} & $\begin{array}{c}\mathbf{0 . 1 \%} \\
\text { humate }\end{array}$ & $\begin{array}{c}\mathbf{0 . 2 5 \%} \\
\text { humate }\end{array}$ & $\begin{array}{c}\mathbf{0 . 4 \%} \\
\text { humate }\end{array}$ & $\begin{array}{c}\mathbf{0 . 5 \%} \\
\text { HSCAS }\end{array}$ & SEM \\
\hline AFB-1 residue & 0.0 & $0.890^{\mathrm{a}}$ & $0.712^{\mathrm{b}}$ & $0.375^{\mathrm{d}}$ & $0.400^{\mathrm{d}}$ & $0.525^{\mathrm{c}}$ & 0.015 \\
\hline
\end{tabular}

$\mathrm{a}, \mathrm{b} \ldots$ and $\mathrm{d}$ : Mean in the same row with different letters are differ significantly at $\mathrm{P} \leq 0.05$.

SEM: Standard error of the mean.

The present study showed clearly that the addition of $0.25 \%$ and $0.4 \%$ humate is the best levels to HSCAS to alleviate the toxic of aflatoxin. The HSCAS is a large molecules and cannot be carried across the intestinal wall and theoretically some of AF compounds escape from HSCAS and across the intestinal wall (Ali, et al.2006). 


\section{Stability of AFB1 in eggs:}

Table (8) showed high stability of $\mathrm{AFB}_{1}$ in contaminated egg after boiling for 5 , 10,15 and 20 minutes, with a negligible mean reduction \% ranged from $0.2-1 \%$. Aflatoxin $\mathrm{B}_{1}$ was almost stable in egg for up to 20 minutes of boiling. Nearly similar findings were reported with Rustom (1997) and Soliman (2002). Heat processing is a common procedure in egg cooking, as regards the safety and nutritive value of egg. It appears to be an effective method for controlling, or even eliminating contamination with Salmonella and Escherichia coli (Tony et al., 2008). Thermal processing was not effective for detoxification of aflatoxin $B_{1}$ in egg. Therefore, avoiding aflatoxin $\mathrm{B}_{1}$ transmission to egg appears to be the only practical way to ensure the safety of egg for human consumption (Wood, 1989 and Bong et al., 2007). So laying hens, should not receive more than $20 \mathrm{ppb}$ aflatoxin in the diet (Dhand et al., 1998 and Bray and Ryan, 2006). The carryover of the aflatoxin metabolites into hens eggs is possible. Therefore, the control of aflatoxin $\mathrm{B}_{1}$ contamination in rations of laying hens is recommended in order to avoid the occurrence of aflatoxin $B_{1}$ in hen eggs intended for human consumption.

Table 8. Stability of AFB-1 in contaminated egg samples $(0.890 \mu \mathrm{g} / \mathrm{kg})$ after heat treatment

\begin{tabular}{lc}
\hline Treatments & Mean AFB1 reduction \% \\
\hline A (Boiling for 5 min.) & 0.20 \\
B (Boiling for $10 \mathrm{~min})$. & 0.50 \\
C (Boiling for 15 min.) & 0.80 \\
D (Boiling for 20 min.) & 1.00 \\
\hline
\end{tabular}

\section{CONCLUSION}

The addition of humate or HSCAS decreased the negative effects of toxicity due to aflatoxicosis in hen diets for all studied criteria and effectiveness. Humate level at $0.25 \%$ was the most successful additive in this study. Further studies must be carried out to study the possibility of using these additives in detoxification of other mycotoxins like ochratoxin, T2- toxin ---- etc.

\section{REFERENCES}

Abd El-Hamid H.S., N.S. Isshak, A. El-Swak and A.A. Mandour, 1992. Effects of feeding low levels of aflatoxin on productive performance, serum constituents and pathological changes in laying Japanese quail. Egypt. Poult. Sci., 12: 347.

Abd El-Hamid A.M., H.S.M. Ariel, F. El-Keraby and T.M. Porra, 1995 . Effect of some dietary supplements to aflatoxin diets of chicks. II. On the tissues analysis. J. Agric. Sci., Mansoura Univ., 20(7): 3227.

Abd El-Maksoud A.M., E.F. El-Daly, B.M. Khashabah and M.A. Galal, 2002. Kidney functions and some blood constituents in Japanese quail. Poult. Sci., 12: 347-375. 
Abo-Norag M., T.S. Edrington, L.F. Kubena, R.B. Harvey and T.D. Phillips, 1995. Influence of hydrated sodium, calcium aluminosilicate and vriginiamycin on aflatoxicosis in broiler chicks. Poult. Sci., 74: 626-632.

Ali M.N., E.M.A. Qota, R.A.Hassan and M.K. Abou-Elmagd, 2006. Novel methods of detoxification of aflatoxin B1 in contaminated local laying hen diets . Egypt. Poult. Sci., vol ( 26): 911-940.

Bogin E. and P. Keller, 1987 . Application of clinical biochemistry to medically relevant animal models and standardization and quality control in animal biochemistry. J. Clin. Chem. Clin. Biochem. J. $25: 873-878$.

Bong J., K. Park, A. Takatori, S. Yoshiko, I. Kim, L. Mi-Hee, H. Dong- Wook, C. Kie-Hyung and O. Soon, 2007 . Degradation of mycotoxins using microwaveinduced argon plasma at atmospheric pressure. Surface and Coatings Technol., 201: 5733-5737.

Bray G.A. and D.H. Ryan, 2006. Mycotoxins, cancer and health. Pennington Center Nutrition Series, $1^{\text {st }}$ Edn. Vol. 1, Louisiana State University Press, Baton Rouge pp: $331-362$.

Clarke R.N., J.A. Doerr and M.A. Ottinger, 1986. Relative importance of dietary aflatoxin and feed restriction on reproductive changes associated with aflatoxicosis in the maturing white Leghorn male. Poult. Sci., 65: 2231.

Dhand N.K., D.V. Josni and S.R. Jand, 1998. Fungal contaminats of dairy feed and their toxigenicity. Indian J. Anim. Sc., 68: 1095-1096.

Decker W.J. and D.G. Corby, 1980. Activated charcoal adsorbs aflatoxin B1. Vet. Hum. Toxical, 22: 388-389.

Dorman H.J.D., S.G. Deans, R.C. Noble and P. Surai, 1995. Evaluation in vitro of plant essential oils as natural antioxidants. J. Essent. Oil Res 7, 645 - 651.

Duncan D. B., 1955. Multiple Ranged and Multiple F-tests. Biometrics 11: 1-42.

Ebied T.A., Y.Z. Eid and M.M. El-Habbak, 2005. Liver and kidney function parameters in ovian species. A review. 3rd International Poult. Conf., Aprl. 4-7 Hurghada, Egypt.

El-Sebai A., 2005. Influence of aflatoxin B1 contamination on renal functions and blood biochemical parameters of Alexandria cockerels. Egypt. Poult. Sci., 395414.

Egyptian Feed Composition Tables for Animal and Poultry Feedstuffs, 2001. Technical bulletin No. 1. Central Lab. for Feed and Food, Ministry of Agric., Egypt.

Fabien G. and K. Ulrich, 2007. Influence of a thermal treatment on the functionality of hens egg yolk in mayonnaise. J. Food Eng., 78: 648-654.

Giambrone J.J., D.L. Ewert, R.D. Wyatt, C.S. Eidson, 1979. Effect of aflatoxin on the humoral and cell-mediated immune systems of chicken. Am. J. Vet. Res., 39: 305-308.

Hoehler D. and R.R. Marquardt, 1996. Influence of vitamins E and C on the toxin effects of ochratoxin A and T-2 toxin in chicks. Poultry Sci. 75, 1508-1515.

Huwing A., S. Freimund, O. Kappeli and H. Dutler, 2001. Mycotoxin detoxication of animal feed by different adsorbents. Toxicology letters. 122:179-188.

Islam K.M.S., A. Schumacher and J.M. Gropp, 2005. Humic acid substances in animals agriculture. Pakistan J. Nutr., 4: 126-154. 
Kubena L.F., T.S. Edrington, C. Kamps-Holtzapple, R.B. Harvey, M.H. Elissalde and G.E. Rottinghaus, 1995. Effects of feeding fumonisin B1 present in Fusarium moniliforme culture material and aflatoxin singly and in combination to turkey poults. Poult. Sci. 74:1295 $\square 1303$.

Kumagai S., 1989. Intestinal absorption and excretion of aflatoxin in rats. Toxicol. Appl. Pharmacol., 97: 88-97.

Lake P.E. and J.M. Stewart, 1978. Artificial insemination in poultry in: Ministry of Agric., Fisheries and Food Bulletin No.213, (London, H.M. Stationery).

Mohiddin S.M., 1982. Note on the effects of aflatoxin on testis in poultry . Indian Journal of Animal Science, 52 ( 6): 481 - 482.

Matkovics B., L. Szabol and I. Varga, 1988. Determination of enzyme activities in lipid peroxidation and glutathione pathways. Lab. Diag., 15: 248-249.

Melrose D.R. and J.A. Laing, 1970. Fertility and Infertility in Domestic Animals, 2nd ed. (London, Bailliere indall).

Muthiah J., P.R. Reddy and N.D.J. Chandran, 1997. Effect of graded levels of aflatoxin B1 on semen quality of breeder cocks. Indian Veterinary Journal , 74 (12): 1031- 1033.

Nabney J. and B.F. Nesbitt, 1965. A spectrophotometric method of determining the aflatoxins. Analyst 90:155-160.

Olivera C.A.F., E. Kobashigawa, T.A. Reis, L. Mestieri, R. Albuquerque and B. Correa, 2000 . Aflatoxin B1 residues in eggs of laying hens fed a diet containing different levels of the mycotoxin. Food Additive and Contaminants.,Vol.17(6) : 459-462.

Ortatatli M., M.K. Ciftci, M. Tuzeu and A. Kaya, 2002. The effects of aflatoxin on the reproductive system of roosters . Research in Veterinary Science, 72:29-36.

Piter A. 1998. Natural occurrence of mycotoxins in foods and feeds : an updated review. Rev. Med. Vet., 149: 479-492.

Qota E.M.A., M.N. Ali, R.A. Hossam and M.K. Abo El-Maged, 2005. Detoxification of aflatoxin contaminated local chicken diets using aluminosilicate sodium sulphate and peroxidase enzyme. 3rd International Poult. Conf., Aprl. 4-7 Hurghada, Egypt.

Qureshi M.A., J. Brake, P.B. Hamilton, JR, Hagler and S. Nesheim, 1998. Dietary exposure of broiler breeders to aflatoxin results in immune dysfunction in progeny chicks . Poult. Sci., 77: 812- 819.

Ramos A.J. and E. Hernandez, 1996. In vitro aflatoxin adsorption by means of a montmorillonite silicate. A study of adsorption isotherms. Anim. Feed Sci. Technol. 62, 263-269.

Rizk R.E., N.A. El-Sayed, G.A. Abd-Allah and S.A. El-Deeb, 1993 . The residue of low dietary aflatoxin $\mathrm{B} 1$ and its effect on productivity and reproductivity of local chicken strains. Egypt. Poult. Sci., Vol 13: $301-326$

Ruston I.Y.S., 1997. Aflatoxin in food and feed: occurrence legislation and inactivation by physical methods. Food. Chem., 59: 57-67.

Safamher A.R. and M. Shivazed, 2005. Study effect natural zeolite on performance and biological parameters of broiler chicks during experimental aflatoxicosis. 3rd International Poult. Conf., Aprl. 4-7 Hurghada, Egypt.

SAS Institute, 1994. SAS/STAT User's Guide: Statistics Ver. 6.04 fourth Edition. SAS Institute Inc., Cary, NC., USA. 
Sharlin J.S., B. Howarth, F.N. Thompson and R.D. Wyatt, 1981. Decreased reproductive potential and reduced feed consumption in mature White Leghorn males fed aflatoxin. Poult. Sci., 60: 2701-2708.

Sharlin J.S., B.Jr. Howarth and R.D. Wyatt, 1980. Effect of dietary aflatoxin on reproductive performance of mature White Leghorn males. Poultry Science 59 1311-1315.

Shen H.M., C.Y. Shi, H.P. Lee and C.N. Ong, 1994. Aflatoxin B1 induced lipid peroxidation in rat liver. Toxicol Appl Pharmacol, 127: 145-150.

Sheng Q.Y., Z.L. Xing, Z. An-Guo, 2009. In Vitro Evaluation of the Efficacy of Sodium Humate as an Aflatoxin B1 Adsorbent. Australian Journal of Basic and Applied Sciences, 3(2): 1296-1300.

Sur E. and I. Celik, 2003. Effects of aflatoxin B1 on the development of the bursa of Fabricius and blood lymphocyte acid phosphatase of the chicken. Brit. Poultry Sci., 44, $558-566$.

Shotwell O.L., C.W. Hesseltine, R.D. Stubblefield and W.G. Sorenson, 1966. Production of aflatoxin on rice. Appl. Microbiol. 14:425-428.

Shukla S.K. and S.P. Pachauri, 1995. Blood biochemical profiles in induced aflatoxicosis of cockerels. British Poult. Sci., 36: 155-160.

Soliman K.M., 2002. Incidence, level and behavior of aflatoxins during egg roasting. J. Agric. Food Chem., 50: 7477-7481.

Stevenson F.H., 1994. Humus Chemistry: Genesis, Composition, Reactions. $2^{\text {nd }}$ Ed., John Wiley and Sons Inc., ISBN: 9780471594741, pp: 496.

Tony J., Z. Howard, B. Glenn and T. Juming, 2008. Thermal resistance of salmonella and Esherichia coli $\mathrm{k} 12$ in liquid egg determined by thermal death time disks. J. Food Eng., 84: 608-614.

Van Rensburg C.J., C.E.J. Van Rensburg, J.B.J. Van Ryssen, N.H. Casey and G.E. Rottinghaus, 2006. In vitro and In vivo assessment of humic acid as an aflatoxin binder in broiler chickens. Poult. Sci. 85: 1576-1583.

Washburn K.W. and D.F. Nix, 1974 . Arapid technique for extraction of yolk cholesterol . Poult. Sci., 53: 1118- 1122.

Weibking T.S., D.R. Ledoux, A.J. Bermudez and G.E. Rottinghaus, 1994. Individual and combined effects of feeding Fusarium moniliforme culture material containing known levels of fumonisin B1 and aflatoxin B1 in the young turkey. Poultry Sci. 73:1517-1525.

West S., R.D. Wyatt and P.B. Hamilton, 1973. Improved yield of aflatoxin by incremental increases in temperature. Appl. Microbiol., 25: 1018.

Wiseman H.G., W.C. Jacobson and W.C. Harmeyer, 1967. Note on the removal of pigments from chloroform extracts of aflatoxin cultures with copper carbonate. J. Ass. Offic. Agr. Chem. 50:982-983.

Wood G.E., 1989. Aflatoxins in domestic and imported foods and feeds. J.A.O.A.C., 72: $543-548$.

Wogan G.N., G.S. Edwards, R.C. Shank, 1967. Excretion and tissue distribution of radioactivity from aflatoxin B1-14-C in rats. Cancer Res., 27: 1729-1736.

Wolzak A., A.M. Pearson, T.H. Coleman, J.J. Pestka and J.I. Gray, 1985. Aflatoxin deposition and clearance in the eggs of laying hens. Food Chem.Toxic. Vol., (12): $1057-1061$. 
تأثير التغذية على علائق ملوثة بالأفلاتوكسين مع أو بدون هيومات ـ سليكات الصوديوم

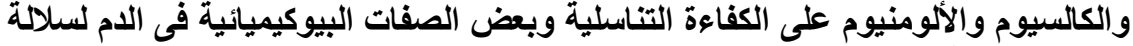

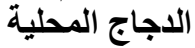

رضا على حسن قسم بحوث تغذية الدواجن، معهل بحوث الإتتاج الحيوانس، وزارة الزراعة، الجيزة، مصر

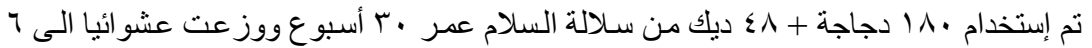

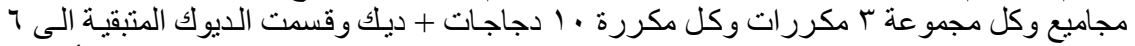

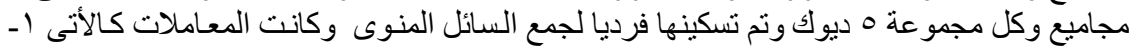

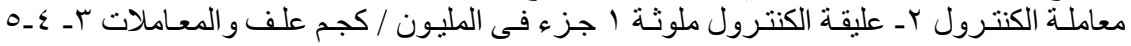

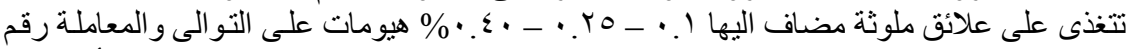

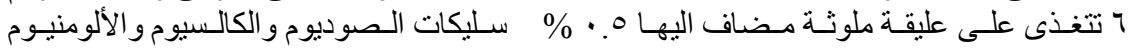

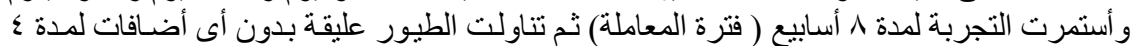

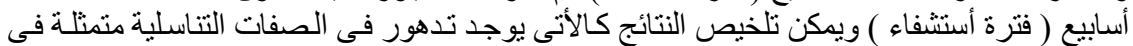

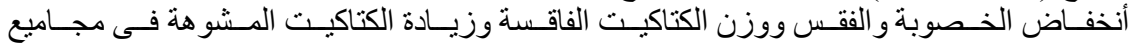

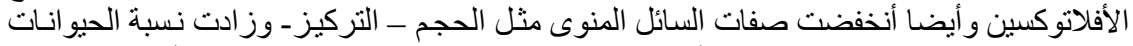

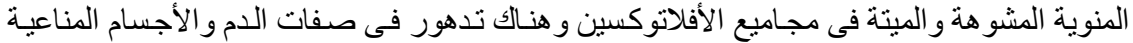

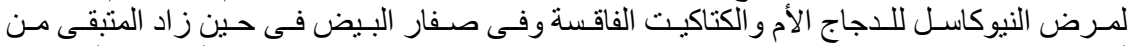

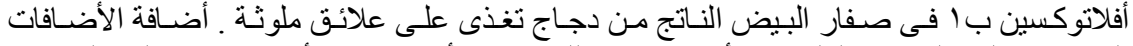

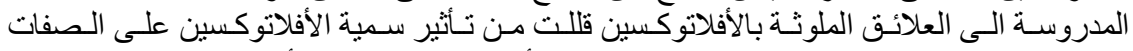
المدروسة خلال فترة المعاملة وساعدت على سر عة الأستثفاء خلال فترة الأستشفاء ـ الألئ 